\title{
Research frameworks, methodologies, and assessment methods concerning the adaptive reuse of architectural heritage: a review
}

\author{
Yuan $\mathrm{Li}^{1,2^{*}}$ (D), Long Zhao ${ }^{1,2}$, Jingxiong Huang ${ }^{1,2}$ and Andrew Law ${ }^{3}$
}

\begin{abstract}
With the growing trend towards preserving global architectural heritage, the adaptive reuse of built heritage buildings is becoming increasingly popular; as commentators have noted, this popularity can in part be attributed to the economic, cultural, and social benefits they provide to urban communities. In considering adaptive reuse, urban developers and planners seek to reach an equilibrium in the battle between time and space. Both academically and practically, the adaptive reuse of heritage buildings requires compatible, appropriate, and scientific means for assessing built heritage assets; however, currently, research in this area is still relatively meagre. To address this gap, this paper investigates research frameworks, methodologies, and assessment methods that concern the adaptive reuse of architectural heritage. In this paper, we examine the current literature on the paradigms for applying mixed methodologies: the multi-criteria decision model (MCDM) and the preference measurement model (PMM). Specifically, in examining the extant literature, we explore the ways in which these methods are discussed, compared, and evaluated, and the positive functions of these methods are also highlighted. In addition, this review examines a range of cases to better clarify the research frameworks, methodologies, and assessment methods used in the study of the adaptive reuse of architectural heritage.
\end{abstract}

Keywords: Architectural heritage, Adaptive reuse, Multi-criteria decision model, Preference measurement model, Literature review and outlook

\section{Introduction}

The adaptive reuse of architectural heritage is about negotiating the transition from the past to the future to secure the historical transfer of heritage assets while also meeting the needs of the contemporary world (Chapman 2004). As a focus in scholarship, the adaptive reuse of architectural heritage has become increasingly linked to political and scientific deliberations (Panwar and Thapliyal 2017).

\footnotetext{
* Correspondence: liyuan79@xmu.edu.cn

${ }^{1}$ School of Architecture and Civil Engineering, Xiamen University, No. 422, Siming South Road, Xiamen 361005, Fujian, China

${ }^{2}$ Xiamen Key Laboratory of Digital Protection and Application for Cultural Heritage, Xiamen 361005, China

Full list of author information is available at the end of the article
}

Academic debates concerning the adaptive reuse of architectural heritage usually refer to those discussions that consider the delicate relationship between heritage preservation and sustainable development, social experiments or approaches to heritage management, adaptive reuse guidelines and the enforcement of preservation plans, and debates concerning the political, economic, and environmental implications of architectural heritage.

While there are many debates in these fields, commentators generally agree that architectural heritage often makes up the core of urban historical resources and is often the carrier of urban cultural values. Moreover, commentators within these debates also often concur that the adaptive reuse of architectural heritage gives 
new life to old buildings and has the potential to help future generations understand their genealogies, including a greater understanding of historical change (Misirlisoy and Gunce 2016). Academically speaking, the value of heritage buildings can be evaluated through multiple lenses. Indeed, some of these lenses include methods for defining standards and innovative protection technologies for restoration and repair, guidelines for the overall management of adaptive reuse, and the establishment of appropriate decision-making systems for selecting the best strategy for adaptive reuse. However, as we have seen, the main problem concerning the adaptive reuse of architectural heritage in the field of conservation is the lack of methods to analyse architectural and historical values, which very often leads to a reliance on individual experience in the process of functional implementation (Günce and Misirlisoy 2014).

Based on the above discussion, this study is concerned with research frameworks for, methodological approaches to, and assessment methods for the adaptive reuse of architectural heritage. The study is divided into four sections. Section 2 discusses the research value of architectural heritage in terms of space and a linear spatiotemporal structure. Section 3 presents a discussion of the research frameworks that are associated with different methodological approaches to and assessment methods for adaptive reuse. Section 4 provides a comprehensive review of the extant literature (2010-2020), and specifically, we investigate the progressive evolution of adaptive reuse and sustainable development with a focus on assessment methods so that we might begin to understand their differences and their applications within a multidisciplinary background. Based on this review, this paper offers a detailed analysis of the key methodologies and methods that facilitate the adaptive reuse of architectural heritage. Furthermore, this study also discusses the effectiveness and limitations of the selected methods we recommend. Finally, in Section 5, we conclude the paper with some outgoing thoughts and suggestions regarding ongoing issues in relation to the assessment methods we analyse.

\section{Adaptive reuse of architectural heritage: the space between past and present}

Theoretically speaking, architectural heritage has historic, documentary, archaeological, economic, social, and even political and spiritual or symbolic value (Dümcke and Gnedovsky 2013). Architectural heritage can be a symbol of cultural identity and continuity (Feilden 2007) within the physical environment, but architectural heritage can also work as a social, cultural, and historical sponge that absorbs everything relevant to the culture, traditions, beliefs, thoughts, religion, ideology, and habits of a society. Heritage, like history, is not a mirror image of the past but is a contemporary use or representation of the past for the present (Sham 2015; Law and Qin 2017). Architectural heritage is therefore important for discussions concerning the ways in which we remember the past (Wang 2017). Thus, architectural heritage plays a role in tracing urban evolution and represents heritage conservation endeavours within a social frame. When adaptive reuse approaches are applied to heritage buildings (Fig. 1), they not only protect the building but also seek to conserve the effort, skill, and dedication of the original builders (Bullen and Love 2009, 2011). The adaptive reuse of architectural heritage seeks to reach a balance between the conservation of buildings and the need to meet contemporary demands, especially spatial and economic demands. Through compatible reuse and appropriate assessment methods, architectural heritage buildings can retain their original facades, historical patterns, layouts, architectural elements, and historical associations while also making a valuable contribution to a modern urban environment and meeting the functional requirements associated with that environment.

The concept of adaptive reuse itself has a sustainability orientation, which needs to be guided by scientific frameworks, methodologies, and methods. Using a bibliometric analysis combined with Scopus and VOSviewer, 208 papers (from 2010 to 2020) were selected using the words 'sustainable AND heritage AND reuse'. As shown in Fig. 2 below, many studies have attempted to combine heritage, adaptive reuse, and sustainable development into a holistic approach to conservation and development. It is worth noting that beginning in approximately 2018-2020, scholars have begun to pay attention to 'strategic approaches', 'assessment methods', 'multi-criteria analyses', 'decision-making processes', 'design strategies', 'human engineering', etc. (Marked yellow in Fig. 2). These studies are extensions of previous studies on 'sustainable development', 'sustainability', 'adaptive reuse', and 'historical preservation' between 2010 and 2017; specifically, as we suggest below, these studies have maintained a considerable degree of relevance to the current field of adaptive reuse in that they have advanced its theoretical development. Therefore, we contend below that the study of research frameworks, methodologies, and assessment methods related to 'sustainable development', 'sustainability', and 'adaptive reuse' will be an important aspect of the development of the extant field in the next few years. As shown in Fig. 3 below, the item density in previous studies reflects these growing topics, which are increasing gradually as hot spots; indeed, as the scatter gram demonstrates, these hot spots are based on 'sustainable development', 'sustainability' and 'adaptive reuse'.

Essentially, value plays a dominant role in the process of adaptive reuse. The use of heritage assets based on 

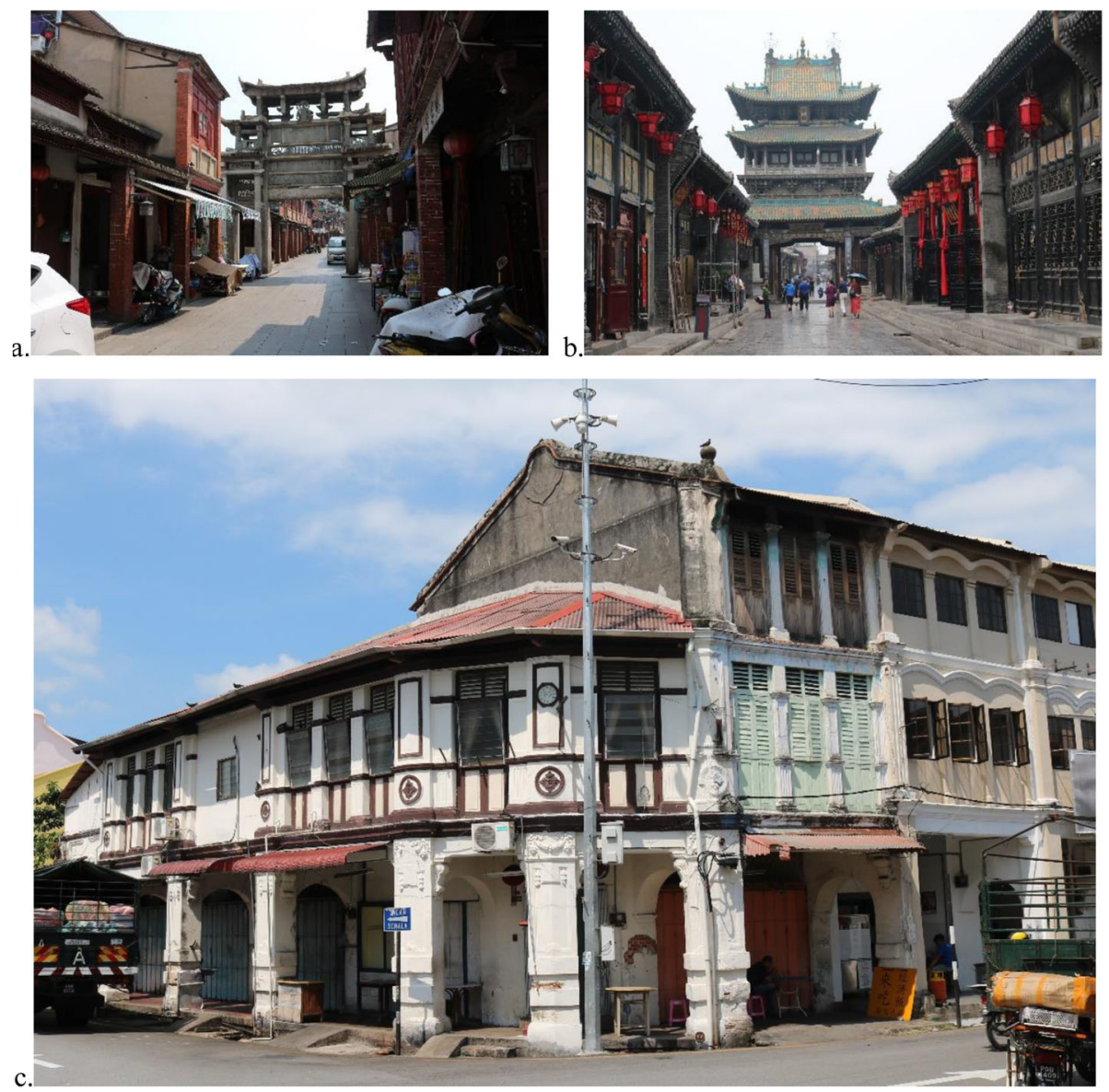

Fig. 1 Historic blocks and their components in the modern era with an adaptive reuse and sustainable development orientation (a Zhangzhou Old Town 2015; b Pingyao Old Town 2018; c George Town 2019). (Source: The author)

systematic value evaluations will benefit the sustainability of regional and historical cultural resources. Researchers such as İpekoğlu (2006) state that the factors that cause architectural heritage to be defined as peculiar urban heritage assets and the evolutionary change in architectural heritage on spatiotemporal linear structures should be considered holistically. Indeed, İpekoğlu contends that 'evaluation studies ... are essential in the context of conservation plans, [and] are inevitable phases to determine the principles of the plans' (İpekoğlu 2006, 386-394). For example, Yıldırım and Turan (2012) propose two types of reuse methods in the study of traditional houses in Sanliurfa, Turkey. In their study, the implementation of adaptive reuse is approached in terms of 1) compatible reuse and 2) most appropriate reuse. Considering the religious histories and heritage value of traditional Sanliurfa houses, the author conducted an assessment of compatible reuse based on four dimensions: artistic value, historical value, social value, and scientific value. Hettema and Egberts (2019) analyse and compare three small shipyards in northwest Europe and propose that the reuse of shipyards provides an opportunity to restore the historical relationship between the town and water. Other types of adaptable reuse methods have been developed by the Danish landscape architect Ellen Braae, who uses a qualitative methodology based on differentiation, continuation, cultivation, and optimisation.

Overall, heritage conservationists and researchers hold the belief that a successful adaptation involves a degree of respect for the existing historical character of a heritage building while also allowing for a change in function that will enhance the character of a building (instead of destroying it) (Department of the Environment and Heritage, Australian Government 2004). As Pendlebury (2008) states, architectural conservation has paradigmatically shifted from a singular focus on protection or preservation to an adaptive reuse approach related to sustainable development and regional growth; from Pendlebury's perspective then, heritage is essentially a cultural practice and social process. Therefore, before the implementation of any adaptive reuse project, it is necessary to conduct a comprehensive assessment of the architectural heritage, as strategies respond to new functions. 


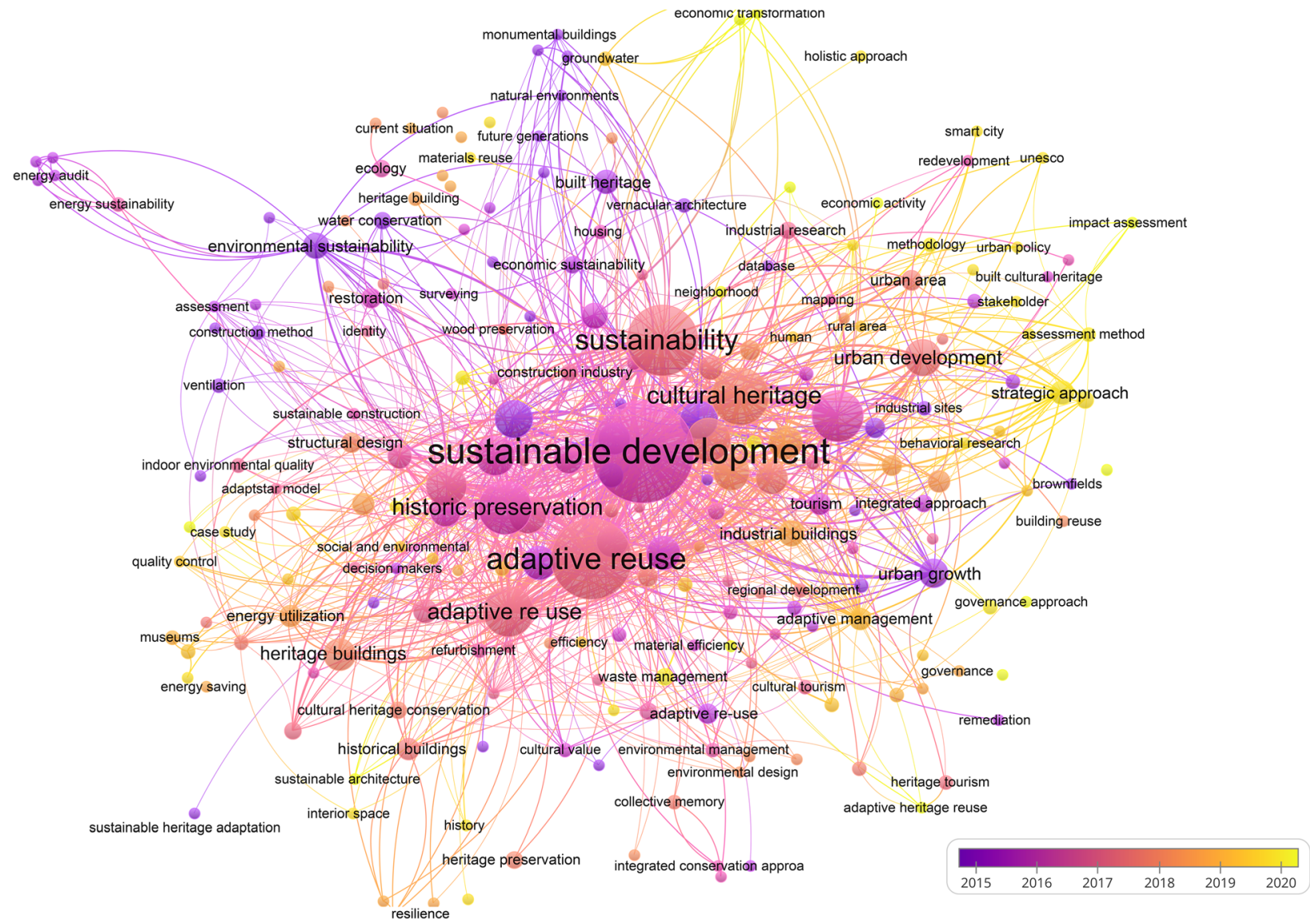

Fig. 2 Research topics and progress concerning sustainable development, architectural heritage, and adaptive reuse from 2010 to 2020. (Source: The author 2021)

\section{Current frameworks for research on adaptive reuse through the lens of sustainable development}

Many current research frameworks proceed with concern for issues of adaptive reuse at the urban or state scale. Discussions concerning research frameworks often present an interdisciplinary and multi-dimensional conceptual model. In essence, the adaptive reuse of architectural heritage provides innovation opportunities for the social, cultural, functional, environmental, and financial needs of the community where the heritage site is located. Moreover, the adaptive reuse of architectural heritage often offers sustainable development solutions to improve local economies, environments and social conditions (Shehata et al. 2015); in this regard, issues of adaptive reuse are tied up with broader discussions about creating balances among social, cultural, functional, environmental, and economic sustainability-based goals. Although researchers have proposed a range of research frameworks for consideration, it is still difficult to strike a balance between the various goals we have addressed in the delivery of adaptive reuse projects. Moreover, the increasing emphasis on adaptive reuse is partly due to the criticisms that many have raised against the practice of renewal and the reutilisation of heritage buildings; indeed, as commentators have argued, current attempts to adapt heritage buildings are too narrow in their scope, and they often fail to reflect the breadth and depth of local history, culture, and society.

Sustainable development, however, is also a complex and contested issue, but on most occasions, discussions and explorations about adaptive reuse always stand on the ground of sustainability theories. Here, in what follows, we select a range of research frameworks as the basis for understanding adaptive reuse in the context of sustainable development. In particular, in taking this approach, we seek to highlight the discussions, debates, and critiques in the scholarship that are based on Campbell's planner's triangle of sustainable planning, social sustainability, the UNESCO historic urban landscape (HUL) approach, the EU's holistic four domain approach, and the heritage conservation policy matrix. These models and approaches primarily focus on sustainability within discussions of different dimensions, and characteristically, they are subordinate to an integral, holistic, and object-based approach. As conceptual 


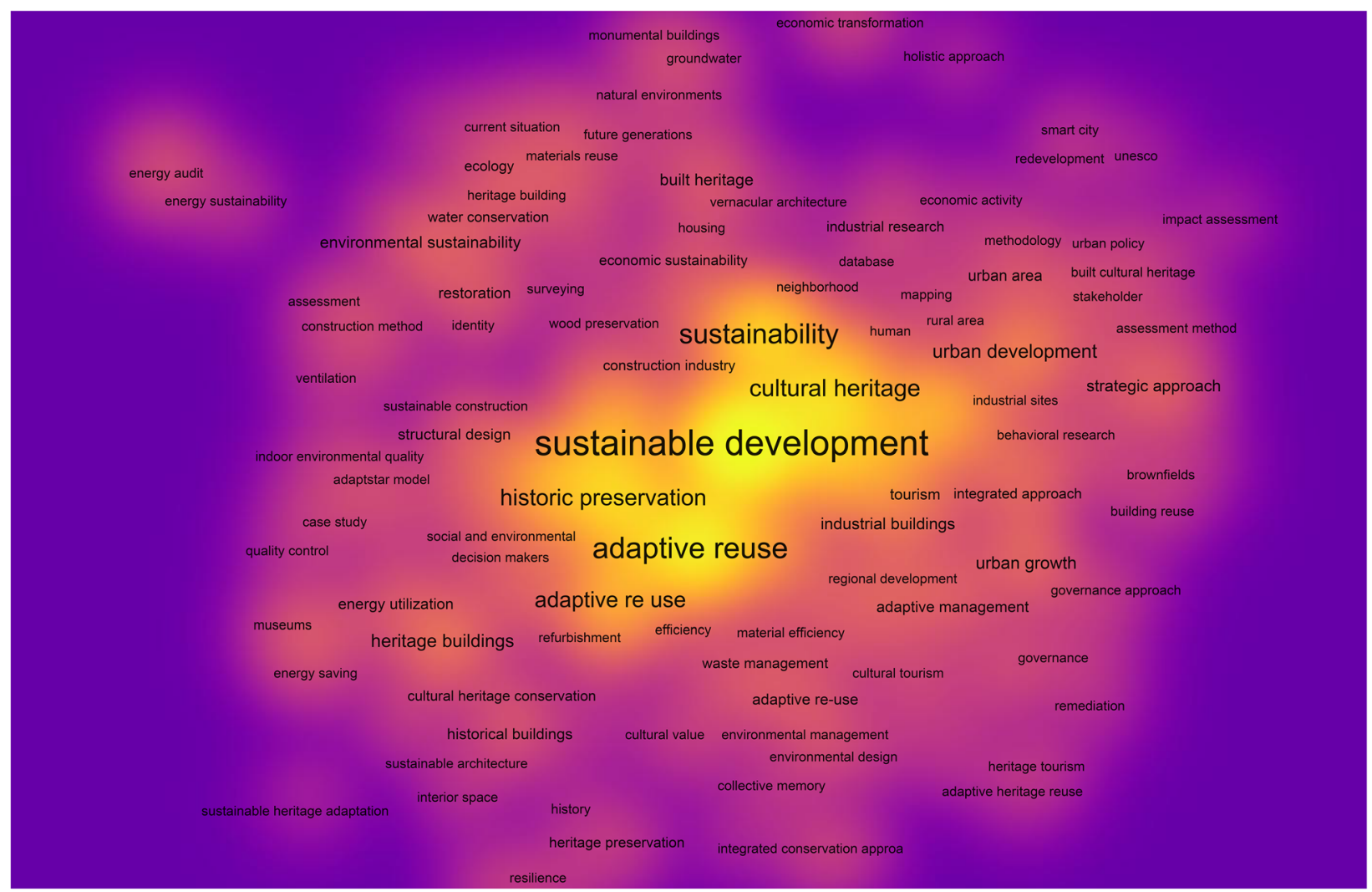

Fig. 3 Item density in previous studies, 2010-2020. (Source: The author 2021)

action guides, or perhaps more precisely, methodological frameworks, they highlight multiple values in achieving a positive vision of sustainable development through the process of justification and assessment in the study of adaptive reuse issues.

Any framework that contributes to the reuse of heritage buildings should incorporate criteria that ensure that adaptive reuse will not affect heritage values and that it will reconcile historic preservation and sustainable design. In terms of sustainability, adaptive reuse is grounded in an integrated and coordinated research framework. Very often, in regard to sustainability issues, a typical debate involves weighing the reciprocal relationships among social, economic, and environmental actors; furthermore, such research often seeks to balance issues of justice and development conflicts through cooperation and the distribution of different benefits. Such a relationship, as shown in Fig. 4, is represented by Scott D. Campbell's planner's triangle, which explores the links between sustainability and urbanisation that reflect perceptions of sustainability as both tensile and resilient in multilevel governance. The planner's triangle for sustainable development involves three basic priorities for planning. Adaptive reuse requires a macro perspective, including considerations of economic development, environmental protection, social justice, and equity.
Campbell (2016) states that resources, property, and development are three interrelated points of conflict. These points of conflict are subject to the positive orientations of society and political institutions, including social welfare, environmental issues, the economy, supervision, and environmental justice. Correspondingly, crossconflict collaboration is represented by diagonal lines on the triangle. These corresponding links (in italics) play a role in building the relationships between the three points of conflict. In architectural heritage planning, it is helpful to alleviate and resolve the social issues caused by these conflicts. This triangular framework also provides a holistic reference plan for planning, collaborating on, and evaluating the adaptive reuse of architectural heritage. According to this view, sustainability can be treated as an ongoing process of resolving conflicts among these three broad planning goals, and the adaptive reuse of architectural heritage has been amplified to become a way to solve social problems, especially those arising in the renewal of old urban areas, old industrial areas and abandoned industrial towns. Campbell's triangle, when applied to the topic of the adaptive reuse of architectural heritage, encompasses internal linkages, external sustainability variables, and interchangeable goals that are in line with the descriptions of UNESCO's sustainable development agenda. 


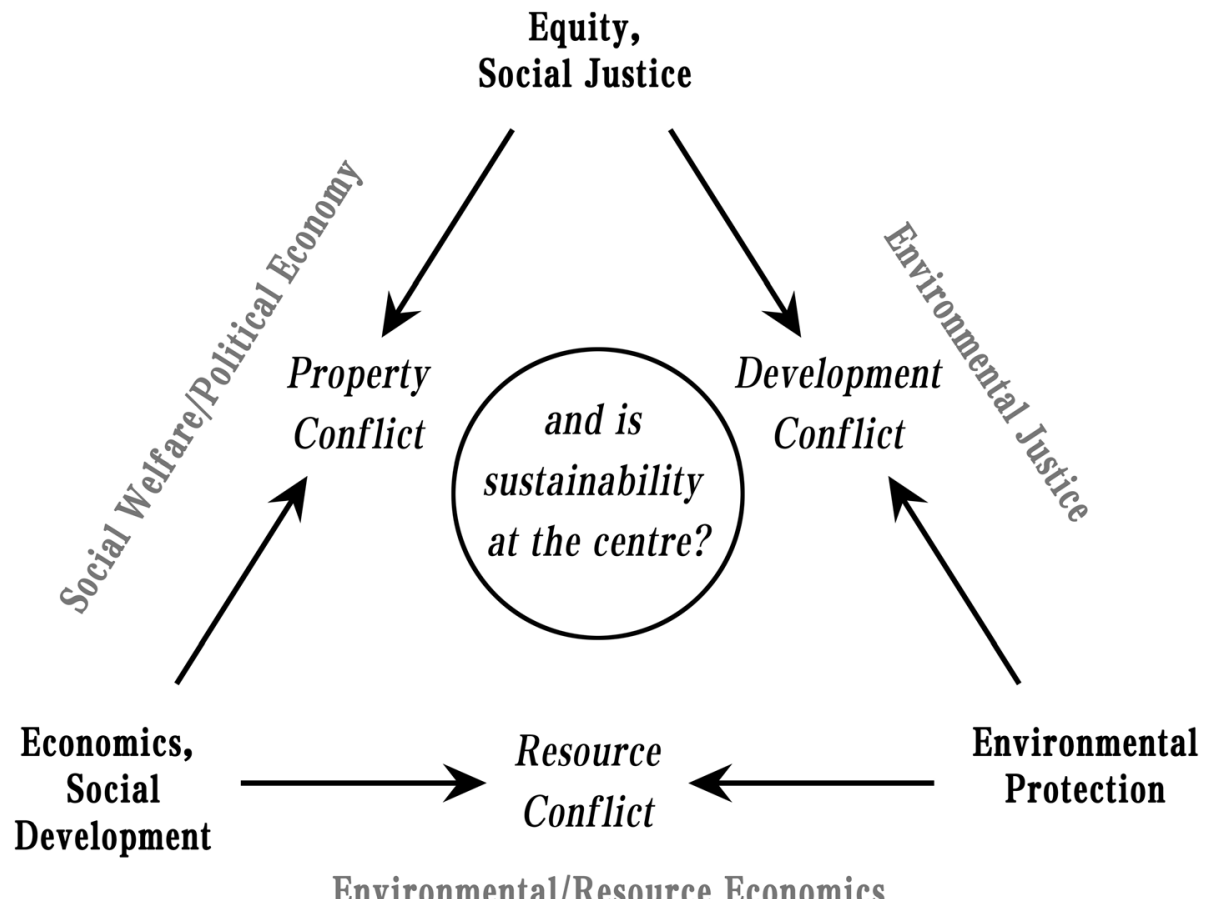

Fig. 4 Planner's triangle for sustainable development by Scott D. Campbell. (Source: Campbell 2016; Modified and Redrawn by the author 2019)

The assessment of the adaptive reuse of architectural heritage is a comprehensive multi-interest process that involves not only the maintenance of historical, economic, scientific, and aesthetic values, etc., but also includes mid- to long-term development visions combined with planning strategies. As Fayad and Kendal (2020) argue, ideal strategic planning practices are often closely linked to local histories and look forward to future visions and demands. From the perspective of planners, Townsend (2015) believes that contemporary strategic planning theories and adaptive reuse have the same goals and require a comprehensive method for evaluation. In fact, for Townsend, this comprehensive approach is based on an interdisciplinary approach, which emphasises the internal and external connections across nature, place, the economy, the community, and psychology. Returning to the topic of the adaptive reuse of architectural heritage, the process of reuse needs to be based on a comprehensive assessment of the values, histories, visions, and communities that exist around the architectural heritage. As shown in Fig. 5, Townsend's five main indicators include a range of sub-indicators that integrate planning practices and the adaptive reuse of architectural heritage as a whole. On a conceptual level, Townsend's circle includes different dimensions and is a logical model of coordination and symbiosis. Moreover, Townsend's circle suggests a model for the structure of planning and conservation methods in which place, planning (participatory and interdisciplinary action), assessment and conservation can be conceived within a broader sustainability framework. With a greater consideration of the adaptive reuse of architectural heritage in the planning process, changes and shifts are continuously integrated into an overall development agenda; here, within Townsend's model, the formation of a final plan would work with multiple sustainable development indicators to resolve the complex issue of the adaptive reuse of architectural heritage within a particular urban history and geography (place). In Townsend's circle, planning aligns with adaptive reuse, which imposes an integrated focus to ensure that scientific and rational goals are met while also conserving the tangible and intangible features that are significant to the sustainability of the city and its overall urbanscape.

In addition to Campbell's planner's triangle and Townsend's circle, other scholars have highlighted the human dimension and have focused on the social relevance of conservation and sustainability. In doing so, as outlined below (Fig. 6), Vallance et al. (2011) present a threefold, progressive model of social sustainability (development sustainability, bridge sustainability, and maintenance sustainability) for the exploration, development, bridging, and maintenance of social sustainability. This model captures the essence of sustainability in social realms and emphasises the reciprocal relationships between both society and sustainability, as well as the conceptual and practical conflicts that emerge. The maintenance of sustainability in Suzanne Vallance et al.'s framework is 


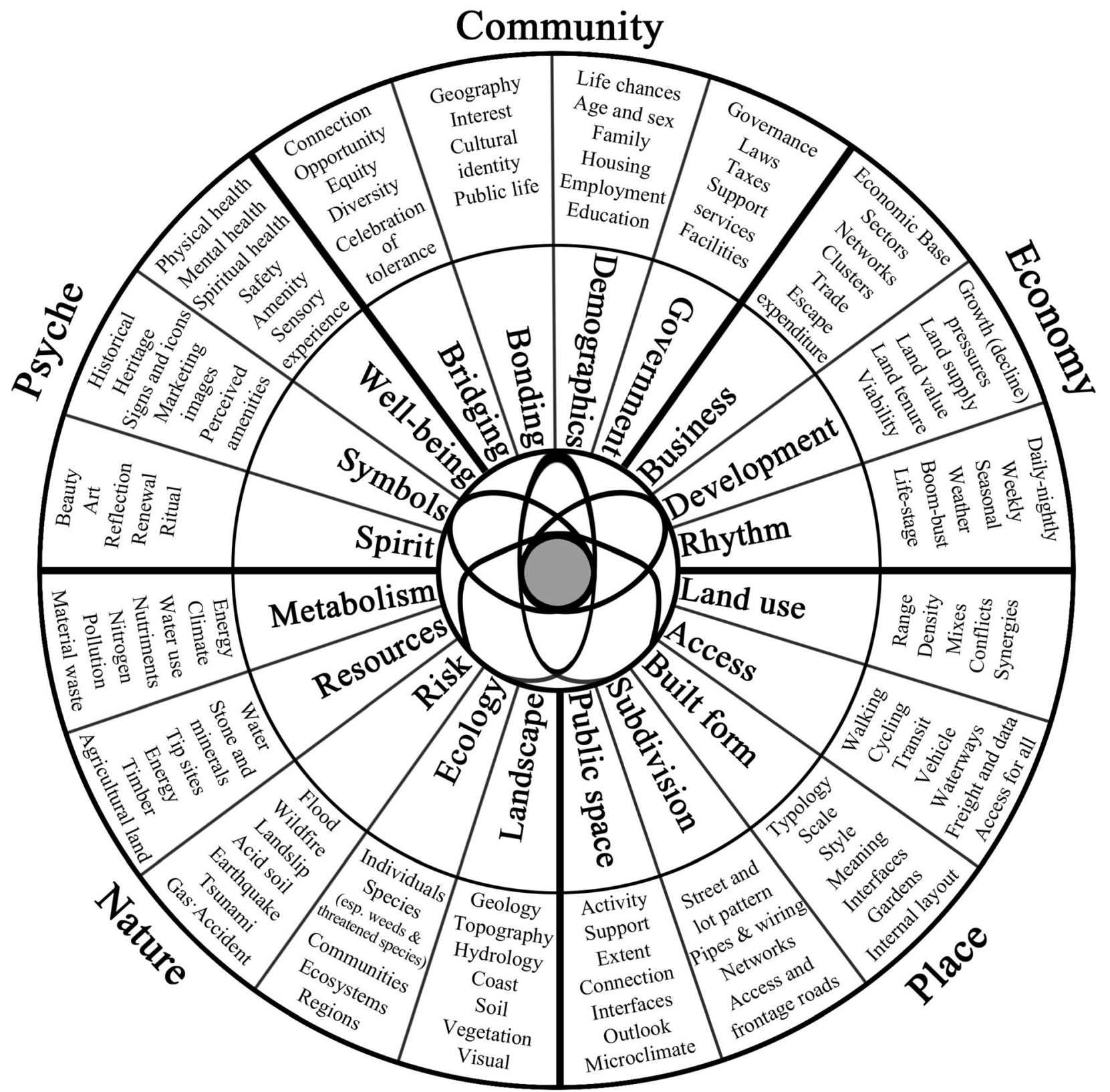

Fig. 5 Contemporary strategic planning theory aligns with the objectives of adaptive reuse by Townsend. (Source: Townsend 2015; Redrawn by the author 2021)

relevant to the socio-cultural aspect of overall social sustainability; specifically, Vallance et al.'s framework concerns the preservation of socio-cultural patterns and practices in the context of constant social and economic change (Vallance et al. 2011). Consequently, within this framework, daily lives are maintained and sustained through a collaborative process that involves different aspects of the urban fabric, as well as the adapted buildings the stakeholders live in. Fundamentally, this approach to sustainability as a cultural tool incorporates development sustainability and bridge sustainability to enable social sustainability; indeed, within this framework, issues that have been neglected in the economic and environmental dimensions are smoothed and reconciled.

The UNESCO Recommendation on the Historic Urban Landscape (the HUL approach) (2011), as a flexible instrument with culture- or heritage-led development concepts, encompasses ideas of adaptation, dissemination, and monitoring (Boom 2018). It provides a holistic framework for the conservation and utilisation of largescale heritage spaces. The adaptive use of architectural 


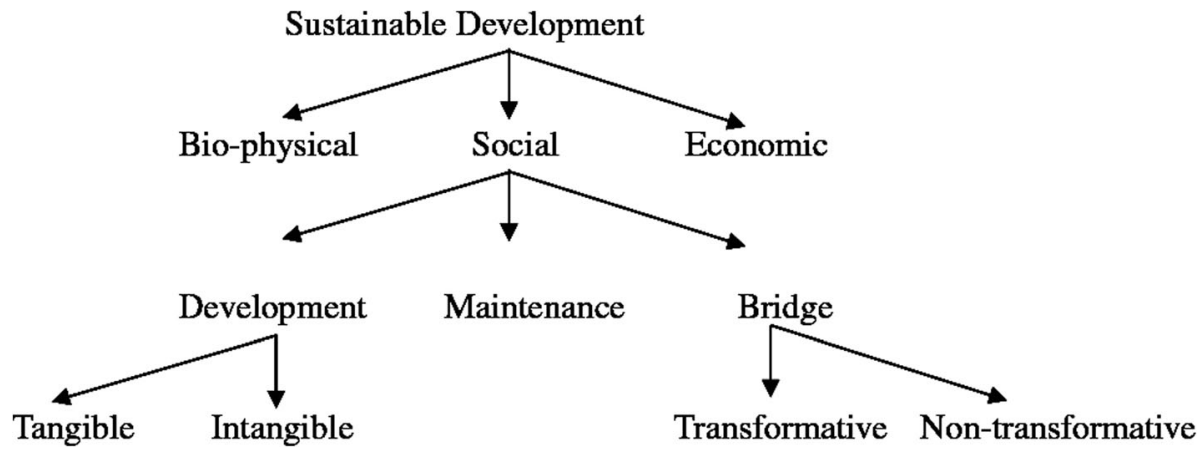

Fig. 6 Three strands of social sustainability. (Source: Vallance et al. 2011; Redrawn by the author 2020)

heritage has become an important factor in maintaining the landscape quality of historic towns. The HUL approach emphasises the importance of cultural diversity, dynamic integrity, and creativity, which creates higher standards for the adaptive reuse of architectural heritage at different scales in the city. The positioning of heritage properties has also risen from regional historical relics to key assets for the socio-economic and cultural development of places, cities, countries, and even the whole of humankind. In fact, the HUL approach emphasises the principles of harmony and continuity, which not only take into account ideas of the dynamic integration, harmony, and sustainability of interventions and heritage in the adaptive reuse process but also consider the continuity of historical backgrounds, cultural contexts, meanings, and heritage values. In terms of the particular implementation of this approach, specific assessment methods should be selected according to the characteristics and reuse potential of the architectural heritage in question. The HUL approach was fuelled by the sustainability vision of the 2011 UNESCO recommendation, which has been considered to be a comprehensive combination of a cluster of links between sustainable development and heritage conservation; furthermore, the HUL approach was also based on the concept of dynamic integrity, which is based on the notion that sustainability should strike balances between urban growth and quality of life (UNESCO 2011; Veldpaus 2015), heritage and the economy, and the time and space in multidimensional cross relations. This approach has been extended to heritage sites around the world to address the economic-versus-preservation conflicts that emerge in the process of managing heritage resources in dynamic and constantly changing environments. The HUL approach supports community efforts to seek long-term developments and adaptations to changing situations while preserving heritage characteristics and the intrinsic historic and aesthetic values associated with local history, collective memory, and the environment. As an important tool in making informed decisions for administrators and policymakers, the HUL approach is based on the interconnections between nature and culture, authenticity and integrity, tangibility and intangibility, public and private needs, and the historic and universal values present in the complex layering of the urban landscape and issues relating to cultural diversity.

The Cultural Heritage Counts for Europe consortium (Europa Nostra 2015) proposes a diagram for a holistic four-domain (cultural, social, environmental, economic) approach concerning sustainable development with various values, as shown in Fig. 7; this framework provides an impact assessment and serves as a basis for supporting the delivery of an integrated policy approach to heritage' in the European Union that guarantees that the multiple benefits of cultural heritage are realised in practice (Whitehand 2014, pp. 477). The four domains cover a wide range of vibrant key fields or 'creator' attributes of sustainable development with actions related to credibility, availability, reliability, creativity, and innovation. Based on the framework presented in Fig. 7, the sustainable development of Europe's cultural heritage is constructed by a range of practical strategies, which include conservation-related construction (authenticity, the liveability of heritage assets); effective marketing strategies (investments, cultural tourism, marketing tools, small and medium-sized enterprises); the fostering of cultural creative quarters (start-ups, indirect and direct jobs, the promotion of creative industries) in regions, cities, towns, and areas; the nurturing of education and lifelong learning (history, civic belonging, skills, cooperation and personal development); and the construction of social capital (social cohesion, connections, interactions, participation and engagement, mutual understanding and integration).

Srinivas (2015) proposes a matrix for heritage conservation policy in order to achieve a good heritage conservation performance. In his opinion, there are two criteria for a good heritage conservation performance: first, the appreciation of the significance of heritage through the consideration of tangible and intangible attributes and second, the construction of conservation 


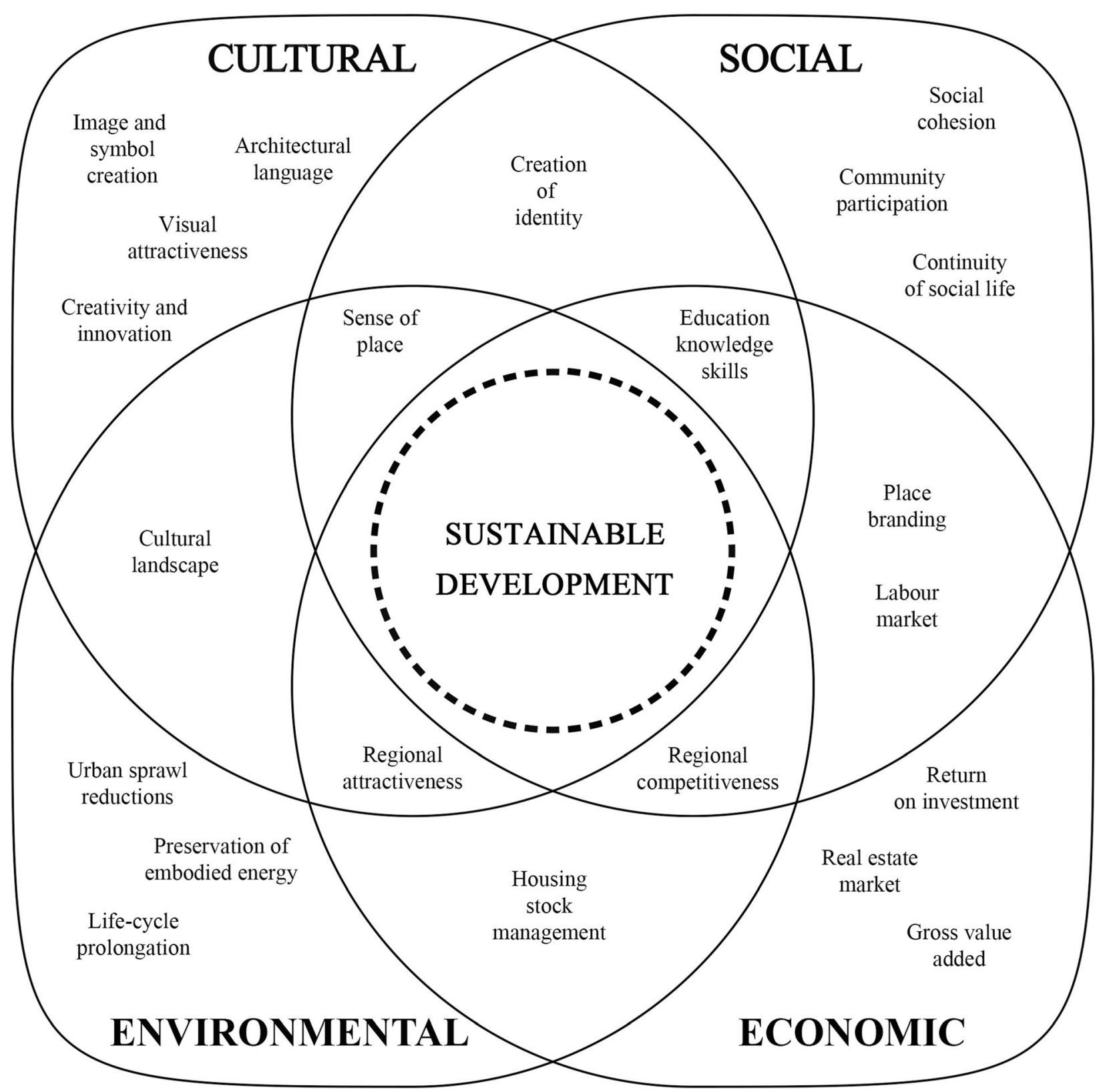

Fig. 7 The holistic four-domain approach diagram. (Source: Europa Nostra 2015; Redrawn by the author 2020)

practices within larger processes of planning and urban development. In Fig. 8, the $\mathrm{x}$-axis measures dimensions concerning the combination of conservation and development from the perspective of heritage development and macro development within cities. The y-axis measures the direct and indirect benefits generated from policy-based heritage conservation at the community level and the city level separately. However, as Srinivas states, the contributing factors in the four quadrants are still insufficient, and a further complementary factor is needed. Even so, the $\mathrm{x}$-axis and $\mathrm{y}$-axis compose a coherent institutional framework. Indeed, the $\mathrm{x}$-axis shows the consideration of development components in the policymaking process, while the $y$-axis outlines the real effects if policymaking is compatible with the interests of cities and communities.

Macroscopically, however, the tensions, barriers, contradictions, conflicts, and imbalances, whether accidental or incidental, within architectural heritage interests are not hard to address within current approaches. At the same time, increasing pressure due to societal issues in historic cities has compounded the difficulty of resolving these tensions, barriers, contradictions, and conflicts. Many studies and projects conducted worldwide have 


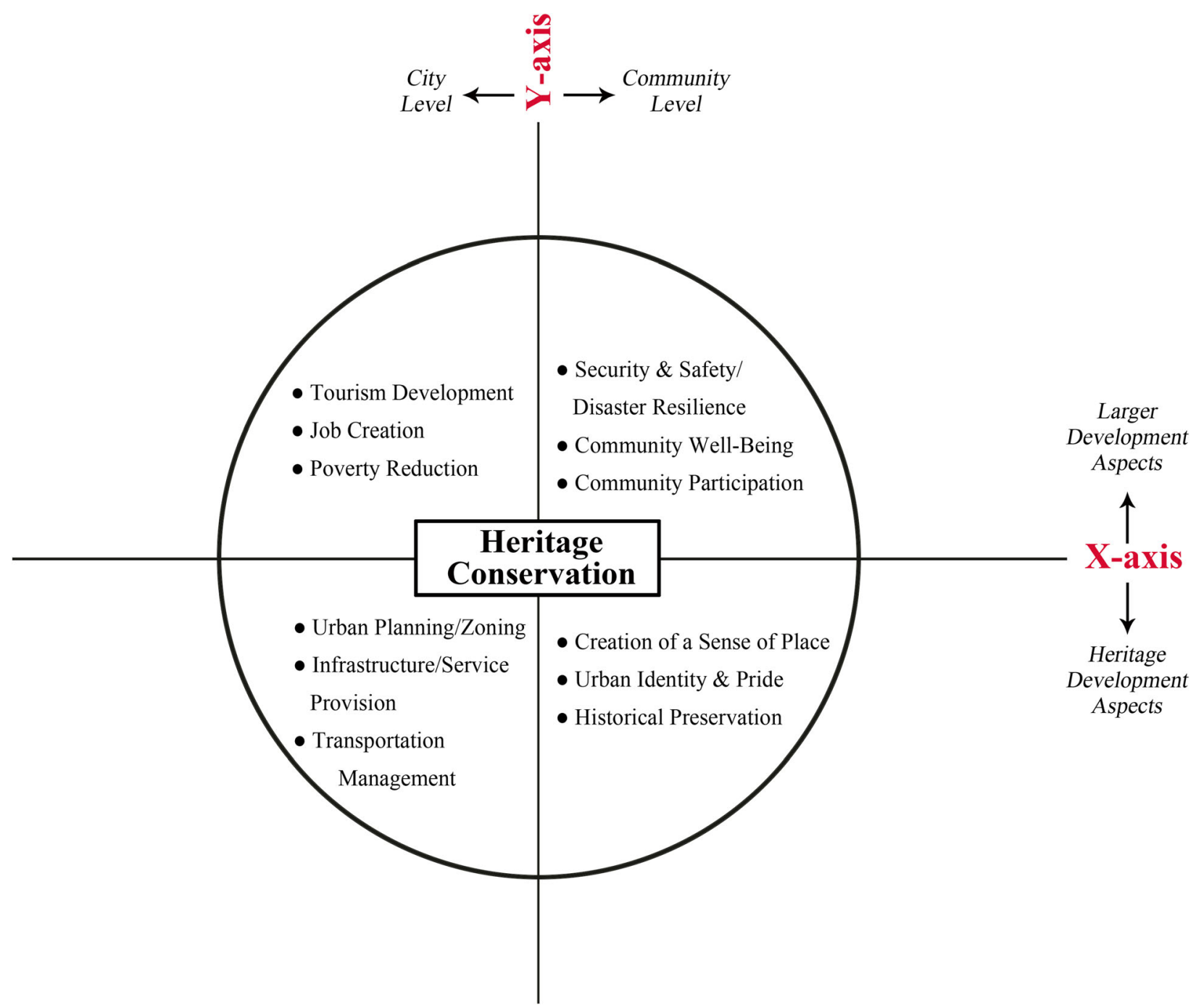

Fig. 8 Heritage conservation policy matrix. (Source: Srinivas 2015; Redrawn by the author 2019)

provided abundant examples of how we might deal with these problems. In what follows, this paper offers an academic analysis of current research frameworks with disparate disciplinary roots; specifically, we examine the current methodologies and assessment methods from the macro and micro perspectives while also focusing on issues of sustainability so that we can begin to generate a strong model of and assessment process for the adaptive reuse of architectural heritage.

\section{Methodology in research and assessment methods of adaptive reuse}

Based on our discussions of space and the current research frameworks, in what follows, we suggest that methodology and assessment methods, as an assemblage for sustainable development and a secure foundation for decision-making, are indispensable components of a holistic strategy for adaptive reuse.

\subsection{Discussions based on the mixed methodology during} the research process

Mixed methodologies are very often employed by researchers in adaptive reuse studies. Compared with discrete quantitative and qualitative data collection approaches and analyses, mixed method-based approaches feature highly integrated collaborative analyses for the overall interpretation of quantitative and qualitative data (Wisdom and Creswell 2013). Moreover, the integration of qualitative and quantitative methodologies can occur at any stage of the research process through research models based on mixed methods; furthermore, this integrative approach allows for the construction of a holistic framework that can then be utilised for adaptive reuse assessments and an analysis of architectural heritage (Glogowska 2011). Based on this methodology in the study of adaptive reuse, an assessment would need an objective collection of quantitative data and describable 
qualitative data, which would then allow data from one source to complement and enhance the other during the analysis and discussion. Hence, at its most basic level, the advantage of complementarity, completeness, and validity means that this mixed-method approach can allow for a detailed exploration of complex phenomena, yielding valid and reliable insights that can guide practice.

Creswell (2010) outlines a mixed-method research framework that is made up of five domains (five MMR: essence, philosophical and theoretical issues, procedures, adoption and use, politicisation); this method particularly deals with key developments, issues, and priorities in the research process. Moreover, Cameron (2011) provides a five-Ps framework for mixed-method research that includes paradigms, pragmatism, praxis, proficiency, and publishing. In discussing the internal logic of the elements within mixed-method research, Morgan (2007, pp. 48-76) summarizes an 'abductive-intersubjectivetransferable' approach to explain and tease out such relationships; this approach links different kinds of data through data interchange and teamwork to generate cooperative and inclusive research results. Thus, the frameworks of Creswell and Cameron and the 'pragmatic approach' of Morgan each provide rather flexible and scientific starting points for the development and progression of research projects.

Using mixed methodologies is not a new approach. In the last two decades, an increasing number of studies have involved the combination of qualitative and quantitative methodologies in the field of architectural studies, urban planning, landscape architecture, heritage conservation and tourist development. Oppermann (2000) contends that in the research process, different types of data sets and investigators can be brought together through multiple methods (particularly in the study of tourism from interdisciplinary perspectives). Amaratunga et al. (2002) discuss the application of mixed methodologies in the field of the built environment. Likewise, Silva and Mosimane (2012) employ mixed-methods assessments in conservation-based rural development studies. McGehee and Andereck (2004) adopt this methodology in the study of sustainable tourism. González-Tennant (2013) adopts mixed methods in the study of social justice and the development of new heritage and dark tourism. Chilisa and Tsheko (2014) open the discourse on mixedmethods research on sustainable intervention outcomes relating to indigenous research. Molina-Azorín and Font (2016) and Khoo-Lattimore et al. (2019) adopt mixed methods in tourism research based on the sustainability and sustainable development perspectives. Berta, Bottero and Ferretti (2016) focus on industrial heritage and urban regeneration with a mixed-methods approach to studying the integration of urban design and economic evaluations. Overall, the above studies represent a broader concern and a scholarly trend that favours mixed methods in that such methods allow for the creation of in-depth information and the mapping of the trajectory of particular research approaches to specific research issues. However, researchers utilising mixed methods in the investigation of the adaptive reuse of architectural heritage are still limited in many respects, and in the next sections, we offer additional ways in which singular projects can be broadened.

\subsection{Discussions based on the multi-criteria decision model (MCDM)}

In responding to the interdisciplinary nature of adaptive reuse, projects need to be assessed in detail and comprehensively (Wang and Zeng 2010); therefore, deciding on new reuse functions for architectural heritage is a difficult problem. Indeed, the decision-making process is complex and diverse since many factors need to be considered (Misirlisoy and Gunce 2016). Some researchers use semi-structured interviews to handle these issues (Elsorady 2020); however, in many cases, researchers often choose a numerical model to quantify problems and propose solutions. According to Mazzanti (2002), analyses of the adaptive reuse of heritage building functions should consider architectural, historical, economic, social, environmental, and/or cultural values. Such an approach, therefore, requires a multi-criteria decision model (MCDM) based on multi-attribute value theory (MAVT), which can then be used to decide the best use and select the best function (Ferretti et al. 2014).

Among the models applied in the previous literature, the analytic hierarchy process (AHP), proposed by Saaty (1988), has been widely tested and used to resolve different decision-making problems. Decision situations to which the AHP can be applied include choice, ranking, prioritization, resource allocation, benchmarking, quality management and conflict resolution (Forman and Gass 2001). Ribera et al. (2020) chose the monumental Palazzo Genovese in Italy and used an AHP model to analyse the social, cultural, and economic value of the reuse function of this architectural heritage through multiple dimensions to obtain the highest valuation and best use. Fedorczak-Cisak et al. (2020) believe that many of the criteria used to evaluate reuse are interrelated and have a nonlinear nature, which requires a network-based model. Specifically, they use the FWINGS framework (fuzzy extensions on weighted influence non-linear gauge systems) to rank the uses (including issues relating to society, economics, and energy efficiency) of a heritage building in Poland. Bottero et al. (2019) focus on the issue of the adaptive reuse of heritage with a multicriteria decision-making framework that supports particular perspectives and presents a novel application of 
the preference ranking organization method for the enrichment of evaluations (PROMETHEE). This method was also employed by Nadeau and Landry (1986) to design and implement adaptive reuse functions and strategies for heritage buildings in Italy. The model evaluated the performance of nine heritage buildings in seven types of adaptive reuse functions, after which the ranking of the adaptive reuse functions of those heritage buildings was formulated as a reference for decisionmaking.

However, Pavlovskis et al. (2019) believe that the accuracy of traditional MCDMs needs to be improved, and they particularly suggest the use of BIM (building information modelling) to build a 3D model as a data source. Combining scores from different experts to establish a weighted aggregated sum product assessment (WASP AS) model, Pavlovskis et al. (2019) rank the alternative reuse functions of heritage buildings. Vardopoulos (2019) combines fuzzy theory with DEMATEL (decision making trail and evaluation laboratory) to evaluate the reuse functions of the FIX Brewery in Greece. Importantly, this model was also used to support decisionmaking based on the criteria of social, cultural, economic, and environmental factors. Considering the hierarchical dependence existing in the traditional AHP method, Chen et al. (2018) use a fuzzy Delphi method to interview experts. In addition to this approach, they also employ a structural modelling method known as an analytic network process (ANP), which was developed by Saaty and Vargas (2006), to explore the best reuse alternatives and strategies for a heritage building in Taipei. They use ANP to determine the priority of the criteria and cases, and specifically, they clarify the impact of the change through sensitivity analyses. Their results reveal that community activities are the most suitable reuse alternative for heritage buildings, followed by commercial, educational, exhibition-based, and mixed-use functions.

Figure 9 illustrates several comparative MCDM applications involving the adaptive reuse of heritage buildings. MCDM is applied in the adaptive reuse of heritage buildings mainly to deal with complex decisions involving multiple criteria. These models are based on expert opinion and quantify the specific results obtained from the value analysis mentioned before. In addition to considering a set of possible decision-making alternatives with their defined characteristics, these models can also process data describing the attributes and indicator values of heritage buildings; moreover, these models allow for the ranking of alternatives according to indicators or attribute values corresponding to different reuse functions to obtain an optimal solution. In general, the wide application of MCDM within research on the adaptive reuse of heritage buildings proves the necessity of decision-making when considering the reuse and changing functions of a heritage building. The application of MCDM also demonstrates the possibility of multi-group participation and can solve qualitative decision-making problems by providing quantitative data. Thus, MCDM is an important tool for decisionmaking institutions, evaluators, and other agents when facing adaptive reuse agendas for a heritage site.

However, although scholars may have introduced fuzzy set methods to improve the degree of objectivity and the accuracy of the models' evaluation results, MCDMs still rely on expert opinion. Indeed, score determination and the accuracy of the assessment results may be affected by the invited scorers (Mualam and Alterman 2020). Considering the representativeness of the decision-making issues and the experts' opinions, MCDM is mostly used to determine the rank of adaptive reuses of heritage buildings or to provide a reference scheme. Advanced researchers have frequently developed five-level models for selecting projects based on ANP, or they have used fuzzy theory to evaluate adaptive reuse projects in the face of uncertainty in the evaluations.

\subsection{Discussions based on the preference measurement model (PMM)}

Over the past two decades, due to the rise of 'bottomup' research methods in the field of heritage protection, public participation in the decision-making process has become a new issue for investigators (Yung and Chan 2011). In particular, researchers have been troubled by expert scoring methods, which do not seem to capture the expressions and interests of stakeholders. Moreover, investigators have also noted that the public may lack adequate knowledge about heritage conservation, which can prevent the public from participating in decisionmaking mechanisms (Coeterier 2002). The European Leader Association for Rural Development (2016) stated that '[the] bottom-up (BU) processing approach means that local actors participate in decision-making about the strategy and in the selection of the priorities to be pursued in their local area'. This approach is therefore focused on community participation, and it is worth noting that the bottom-up processing approach is not considered to be an alternative to (or even in opposition to) the top-down (TD) processing approach; rather, the bottom-up processing approach is seen as incorporating the TD approach, with ideas from both of these approaches being combined and interacting. Both approaches are united in that they both seek to identify the coupling mechanisms among adaptive reuse, preservation, sustainability, and architectural heritage.

Khadka and Vacik (2012) compare the top-down and bottom-up approaches in the identification of criteria and indicators; in particular, Khadka and Vacik suggest 


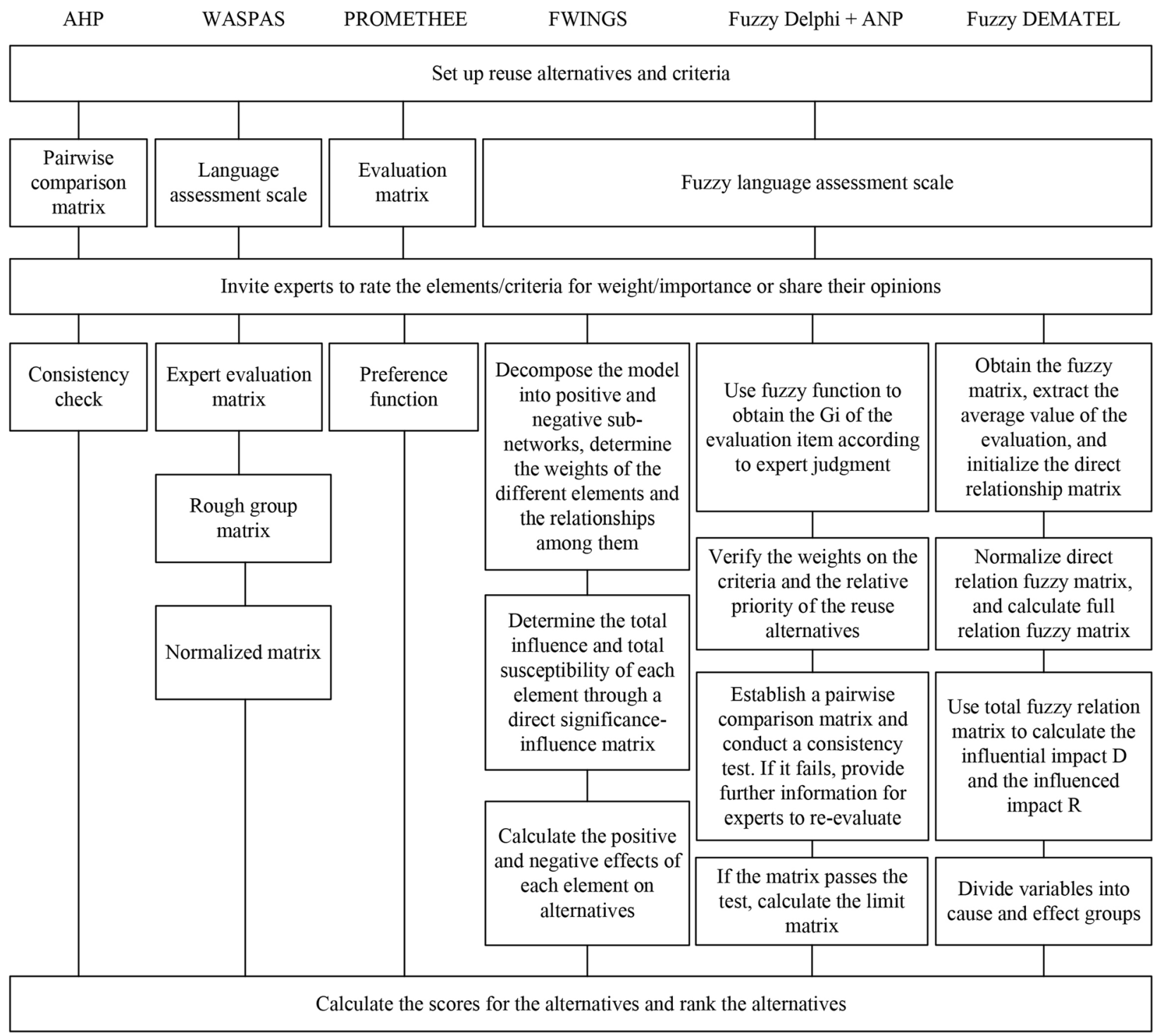

Fig. 9 MCDM applications involving the adaptive reuse of heritage buildings. (Source: The author 2020)

that some of the content, for example, the involvement of multi-way cooperation and the combination of the TD and BU approaches, can be used in research processes for adaptive reuse, as shown in Table 1. Moreover, these authors suggest that a range of steps are present in the BU process, which encompasses expertdriven and community-driven inputs that can be treated as mutual references. Sokołowicz and Przygodzki (2020) provide a good example of these new bottom-up methods. They introduce interdisciplinary research methods to supplement the decision-making process related to the adaptive reuse of heritage buildings from an economic perspective. Visitors' willingness to pay (WTP) can be measured and used to maximise the value of heritage buildings as supplementary content. Specifically, Sokołowicz and Przygodzki (2020) take a twentieth- century post-socialist train station in Poland as a case study and use a three-stage assessment method to understand residents' and visitors' views of these heritage buildings and their preferences for adaptive reuses. Having conducted the study, they propose that research into people's WTP should be the first step for further in-depth research on the adaptive reuse of heritage buildings.

According to the people-centred (PC) approach, 'cultural heritage has been created by people and it has been created for people' (ICCROM 2015). Taking a people-centred approach in adaptive reuse studies not only includes increasing participation in the management, decision-making mechanisms, reuse, and space optimization of architectural heritage but also includes involving individuals or groups that are related to the heritage properties. The inclusion of 
Table 1 The operation of the BU approach to studying the adaptive reuse of architectural heritage based on the preference measurement method

\begin{tabular}{|c|c|c|c|c|c|}
\hline \multirow[t]{2}{*}{ Process } & \multirow[t]{2}{*}{ Objectives } & \multirow[t]{2}{*}{ Tools/methods } & \multicolumn{3}{|l|}{ Expected inputs } \\
\hline & & & Expert-based & Community-based & Outcomes \\
\hline $\begin{array}{l}\text { i) } \\
\text { Information } \\
\text { analysis }\end{array}$ & $\begin{array}{l}\text { Generate a shared } \\
\text { understanding of the } \\
\text { concept of and the values } \\
\text { in the criteria and } \\
\text { indicators }(C \& I) \text { system } \\
\text { and the current situation }\end{array}$ & $\begin{array}{l}\text { Desk study, } \\
\text { documentation and } \\
\text { content analysis }\end{array}$ & $\begin{array}{l}\text { Literature review, identify } \\
\text { the generic C \& I set and } \\
\text { system boundaries, } \\
\text { knowledge gaps, needs } \\
\text { and expectations, and } \\
\text { conduct training }\end{array}$ & $\begin{array}{l}\text { Critical reflection, } \\
\text { communication/knowledge } \\
\text { sharing, stakeholder } \\
\text { interactions, and dialogue }\end{array}$ & $\begin{array}{l}\text { Team formation } \\
\text { and boundaries } \\
\text { for areas (e.g., site } \\
\text { selection) }\end{array}$ \\
\hline $\begin{array}{l}\text { ii) Awareness } \\
\text { building }\end{array}$ & $\begin{array}{l}\text { Understanding } \\
\text { architectural heritage and } \\
\text { the direction of adaptive } \\
\text { reuse }\end{array}$ & $\begin{array}{l}\text { Discussion, stakeholder } \\
\text { analysis, meetings, bio- } \\
\text { physical, socio- } \\
\text { economic, policy and } \\
\text { SWOT analyses }\end{array}$ & $\begin{array}{l}\text { Sharing ideas and } \\
\text { experiences, system } \\
\text { boundaries, facilitating the } \\
\text { future direction of co- } \\
\text { learning environments }\end{array}$ & $\begin{array}{l}\text { Formulating problems, } \\
\text { reflecting, sharing } \\
\text { knowledge, experiences, } \\
\text { views, skills, perspectives, } \\
\text { values and capacities and } \\
\text { desires for the future and } \\
\text { creating the strategy }\end{array}$ & $\begin{array}{l}\text { Improve } \\
\text { understanding } \\
\text { and practices and } \\
\text { realise complex, } \\
\text { dynamic and } \\
\text { multi-level } \\
\text { outcomes }\end{array}$ \\
\hline $\begin{array}{l}\text { iii) } C \& \text { I } \\
\text { development }\end{array}$ & $\begin{array}{l}\text { C \& I development and } \\
\text { formulation of } \\
\text { management strategies }\end{array}$ & $\begin{array}{l}\text { Training/visioning } \\
\text { workshops, focus group } \\
\text { discussions, assessment, } \\
\text { and multiple criteria } \\
\text { analysis (MCA) } \\
\text { approaches }\end{array}$ & $\begin{array}{l}\text { Facilitating system } \\
\text { approaches/perspectives, } \\
\text { searching for common } \\
\text { ground and linking future } \\
\text { visions }\end{array}$ & $\begin{array}{l}\text { Visioning and goal setting, } \\
\text { planning and decision } \\
\text { making, identifying key } \\
\text { priority areas and knowledge } \\
\text { gaps, dealing with risk and } \\
\text { uncertainty, and developing } \\
\text { management strategies for } \\
\text { the desired future }\end{array}$ & $\begin{array}{l}\text { C \& I development } \\
\text { and evaluation } \\
\text { criteria }\end{array}$ \\
\hline $\begin{array}{l}\text { iv) } \\
\text { Preference } \\
\text { elicitation }\end{array}$ & $\begin{array}{l}\text { Field verification and C \& I } \\
\text { assessment }\end{array}$ & $\begin{array}{l}\text { Participatory resource } \\
\text { mapping, social } \\
\text { mapping, field visits, } \\
\text { transects, household } \\
\text { surveys, and multiple } \\
\text { criteria techniques }\end{array}$ & $\begin{array}{l}\text { MCA tools, techniques, } \\
\text { and scenario analyses }\end{array}$ & $\begin{array}{l}\text { Communication and } \\
\text { knowledge sharing regarding } \\
\text { multiple directions and } \\
\text { preferences }\end{array}$ & $\begin{array}{l}\text { Weight criteria, } \\
\text { indicators, and } \\
\text { qualitative and } \\
\text { quantitative } \\
\text { assessments }\end{array}$ \\
\hline $\begin{array}{l}\text { v) } \\
\text { Application }\end{array}$ & $\begin{array}{l}\text { Appropriate collective } \\
\text { actions }\end{array}$ & $\begin{array}{l}\text { Meetings, reflection, } \\
\text { working strategies, and } \\
\text { the formation of sub- } \\
\text { action groups }\end{array}$ & $\begin{array}{l}\text { Data collection and } \\
\text { dissemination, analysis of } \\
\text { results and of } \\
\text { management options }\end{array}$ & $\begin{array}{l}\text { Management decisions, } \\
\text { effective conflict } \\
\text { management, approvals, } \\
\text { policy implications, self- } \\
\text { assessment, and periodic } \\
\text { review }\end{array}$ & $\begin{array}{l}\text { Management } \\
\text { strategies, self- } \\
\text { assessment re- } \\
\text { ports, and } \\
\text { finalisation }\end{array}$ \\
\hline
\end{tabular}

Source: Modified from Khadka and Vacik 2012

people forms an integral part of the overall system of sustainable development (ICCROM 2015) and retains the focus on sustainable development's more qualitative and humanistic characteristics. Contextualized within the background of PC development, existing research is very frequently conducted through questionnaires and/or interviews. In addition to common direct scoring methods, there are semantic differential (SD) methods, stated preference (SP) tools, and means-end chain (MEC) apparatuses.

In practice, the direct scoring and SD methods ask interviewees to score existing scenarios in order to find their preferences based on different algorithms. Of the two, 'the direct scoring method asks decision-makers to specify numerical values for the expected performance of decision alternatives measured against multiple objectives' (Suedel, Kim, and Banks 2009, 3). Najd et al. (2015) conduct a study of public perceptions to identify the visual preferences of international tourists for the historic centre of Kuala Lumpur. They use a five-point Likert scale $(1=$ not preferred and $5=$ most preferred $)$ to explore visitors' preferences $(n=308)$ in combination with photo-based questionnaires (objective evaluations) and text-based short descriptions (subjective evaluations) based on a convenience sampling method. The qualitative and quantitative data are analysed through a descriptive analysis, data reduction techniques, principal component analysis with Varimax rotation and Kaiser normalization, and content analysis. From the perspective of an analytical method, their approach is based on the human perspective so as to explore the optimal use and rational protection of architectural heritage. Consequently, the results of their study remind developers that the appearance and legibility of architectural heritage play an important role in demonstrating the characteristics of historic districts. In the historic environment, architectural heritage is the most obvious factor contributing to legibility. Once the adaptive reuse of architectural heritage is carried out, the architectural heritage itself and its surrounding environment must continue to conform to its historical characteristics in order to preserve the legibility of the heritage assets (Najd et al. 2015). Stober et al. (2018) use a Likert scale to 
investigate the preferences of domestic tourists for visiting pustara settlements. Their approach differs from that of Deghati Najd, Ismail, and Maulan, et al. in that they focus on quantitative data while employing absolute and relative frequencies. Indeed, Stober, Brkanić, and Lončar employ this approach so that they can generate categorical data and use the median and interquartile ranges to calculate numerical data; moreover, this approach allows them to test the normality of the distributions of the numeric variables and the differences between the numeric variables in independent groups. Furthermore, by employing three or more groups of variables, Stober, Brkanić, and Lončar can use the Shapiro-Wilk test, the Mann-Whitney U test, and the Kruskal-Wallis test. With their analysis of the visitors' responses, they rank the most interesting heritage content in the area. To some extent, the total score acts as a reference concerning the functional adjustment of architectural heritage and can also be used to guide the restoration of heritage buildings.

According to Osgood et al. (1957), SD analysis mainly includes three factors: evaluation, potency, and activity. In practical applications, the number of factors to be included, including either one or three at the same time, may be selected on the basis of the research purposes. However, it is customary to use three or more measures for each factor. SD methods allow for the adoption of an auxiliary decision-making effect on the adaptive reuse of different heritage buildings based on real-world experiences. At the core of the SD method is the semantic differential scale, which creates a series of two-way adjective scales based on comparisons of different scenarios. This scale requires respondents to answer a series of pre-set questions to capture their feelings related to their understanding of particular words. It is essentially a method of quantitative subjective evaluation used to obtain respondents' preferences for decisionmaking references. Kang and Zhang (2002) conduct semantic differential analysis on the soundscapes of open urban public spaces, and they conduct their study in three stages. Specifically, Kang and Zhang utilise a pilot study, more detailed interviews, and several soundscape walks to examine the differences between designers and the general public. Ma et al. (2018) conduct a systematic review concerning semantic differential method applications to indoor and outdoor sounds through the use of meta-analysis; specifically, their study analyses the human perceptual dimensions of sound and their corresponding content. Through a systematic review, their study provides suggestions for the use of the SD method in the investigation of specific issues; indeed, in their research, the SD method is adopted to evaluate sounds and their corresponding acoustic indexes within indoor and outdoor environments in combination with the psychological perceptions of the occupants; these methods therefore provide data to support the spatial optimization of an acoustic environment or habitat. This approach also has implications for adaptive reuse in that it provides insights into perception evaluations 1) of individuals and groups for spaces or of individuals and groups for heritage values and 2) of individuals and groups for the historical background of the environment in the assessment process. Shao et al. (2019) use SD methods to conduct a survey with 16 adjectives to identify the views of 84 participants concerning 18 buildings from Asian and European countries. Through participants' opinions on comparisons of adaptive reuse designs and through the results of semi-structured interviews, they propose that adaptively reusing old buildings may be better than building new buildings. In addition, according to the SD survey, architects have a responsibility to lead efforts towards sustainable and creative lifestyles in the future.

However, SD methods are based on factual and realistic behaviours, which do not play a role in the evaluation of preferences for the adaptive reuse of heritage buildings that the public has not visited or cannot visit. In contrast, SP methods can be used to design virtual scenarios based on the different levels of different influencing factors to build a discrete choice model for respondents. At the core of the SP method is random utility theory. This theory is based on the idea that researchers can build a discrete choice model by selecting several element items and levels and can then collect visitors' behaviour preferences for virtual scenes using conditional logit models or multinomial logit models to fit respondents' preferences for different scenarios. These models obtain utility values corresponding to different element levels and assist decision-making by calculating the utility values of different adaptive reuse schemes for heritage buildings (Kroes and Sheldon 1988). Glumac and Islam (2020) use Eindhoven as a case study and use SP methods to generate a model (including six attributes of housing preferences) to measure users' preferences for adaptive reuses of heritage buildings. The research results show the occupants' preferences for space and experiences after renovations. Additionally, the researchers verify their results for the users' preferences. Based on their research and verification results, the researchers explore adaptive reuse frameworks to be able to promote an efficient and economically sustainable framework. The reuse of architectural heritage provides references for evaluation methods, utilisation intensity, and occupants' acceptance. Oppio et al. (2017) establish an SP model to support the design of adaptive reuse strategies for three-mostly unused-castles in northern Italy by carrying out choice experiments. These experiments use the attributes of multi-functionality, 
conservation, exclusivity, interaction, and the costs of inhabitants and tourists in order to understand the preferences of residents and tourists and their willingness to pay for different adaptive reuse functions.

In contrast to the SD method mentioned above, the MEC method uses interviews as the main tool in the research process. Means-end chain theory predominantly represents three cognitive levels of abstraction that are hierarchical in nature: attributes (means), consequences, and values (ends) (McIntosh and Thyne 2005). This method is based on the idea that personal value is the ultimate outcome that motivates goal-seeking behaviour in people. This method uses a series of pre-set questions to obtain the interviewee's preferences for product attributes and the resulting product benefits. This forms a chain of means and ends, and as a result, the researcher can learn how interviewees are attracted to different attributes in order to understand their preferences. The application of means-end chain theory is also related to the adaptive reuse of architectural heritage within a heritage preservation context in that this theory is often used to examine and investigate tourist perceptions and preferences (Katahenggam 2020; Lin and Fu 2020), visitor meanings and motivations (Wassenberg et al. 2015; Ho et al. 2015; Jiang et al. 2015; Esfandiar and Bapiri 2016), and heritage tourism experiences (Willson and McIntosh 2010; Abascal 2019; Bapiri et al. 2020; Tu 2020). Wassenberg, Goldenberg, and Soule employ the MEC method to investigate the links visitors make between sites (such as botanical gardens) in terms of their attributes, consequences, and values by conducting inperson interviews. Based on means-end theory, they form a means-end content code list, which they then apply to the participants' responses to create hierarchical value maps (HVMs) (Klenosky 2002; Jiang et al. 2015; Abascal 2019). As McIntosh and Thyne (2005) state, the MEC method is employed by researchers to evaluate personal values related to tourism activities and experiences. These values are derived from the subjective evaluations of tourists. Through discourse and textual analysis, the influence of tourists' individual values on their behaviour can be inferred to provide a further reference for spatial optimization. To some extent, such an application is similar to the adaptive reuse of architectural heritage in that both approaches use the MEC method to achieve their aims or obtain benefits; the MEC method can therefore be used by preservationists, architects, and planners to justify technical means and methods for adaptive reuse. Abascal (2019) employs the MEC method and convergent mixed-method approaches to identify the link between visitors' perceptions and their intentions towards participation; as was done in Wassenberg's research, an HVM is also created in Abascal's study to interpret the perceptions and understand the motivations of individuals. Bapiri et al. (2020) combine visitor-employed photography (VEP) and the MEC method to identify chains of attributes, consequences, and values. Finally, based on the impact factors of visitor behaviour, Bapiri, Esfandiar, and Seyfi address issues around the fostering of heritage properties by extracting the personal meanings attributed to such cultural heritage sites.

Studies of human preferences also include further research on their decision-making preferences and heritage buildings. The comparison of preference measurement methods in Table 2 shows the differences between current investigations in studies of the adaptive reuse of heritage buildings. Of these methods, the SP method investigates the characteristics of preferences in the virtual environment (Abdullah et al. 2011). This method can accurately measure the influence of the different adaptive reuses of heritage buildings on visitors' preferences and has good predictive power. In contrast, the SD method and the MEC method adopt different perspectives. The SD method is easier to discuss given its use of opposite adjectives in pairwise comparisons, while the MEC method involves the analysis of personal values and behaviour through interviews.

\section{Conclusion}

Overall, with urbanisation moving the global economy forward, increasing preservation, sustainable development within historic cities, and the changes in architectural heritage are perhaps only the outward manifestation of the problems we have discussed in this paper. Conventionally, architectural heritage practices are traditionally associated with four treatment techniques. These include preservation, rehabilitation, restoration, and reconstruction. Therefore, through an appropriate research framework, methodology, and assessment method, promising approaches to adaptive reuse that contain standards and guidelines can be applied and developed during a preservation project. This review brings together a cross-disciplinary collection of the major research frameworks and mixed research methodologies and a range of assessment methods (related to the adaptive reuse of architectural heritage) to construct a systematic description of and framework for analysis. By reviewing past research results from a range of interdisciplinary fields, this paper offers new ways to extend the adaptive utilisation of architectural heritage. On the one hand, this paper provides a variety of research methods for comprehensively and systematically assessing adaptive reuse, which facilitates the selection and adaptation of conservation strategies, such as minimal interventions, the reversibility of actions, liveability, sustainability, compatibility, and 
Table 2 Horizon comparison between preference measurement methods

\begin{tabular}{|c|c|c|c|}
\hline Methods & Semantic Differentials (SD) & Stated Preferences (SP) & Means-End Chain (MEC) \\
\hline Author(s) & Osgood et al. (1957) & Kroes and Sheldon (1988) & Rokeach (1973) \\
\hline Core & Semantic Differential Scale & Random Utility Theory & Means-End Chain Theory \\
\hline Differences & $\begin{array}{l}\text { i) Questionnaire based on the real } \\
\text { environment } \\
\text { ii) Use a series of adjective pairs to } \\
\text { describe the problem }\end{array}$ & $\begin{array}{l}\text { i) Questionnaire based on virtual/real } \\
\text { environment } \\
\text { ii) Control for relationships between } \\
\text { attributes } \\
\text { iii) Strict requirements for the sample } \\
\text { size }\end{array}$ & $\begin{array}{l}\text { i) Semi-structured interviews based on a series of } \\
\text { pre-set questions } \\
\text { iv) Complete investigation through semantic } \\
\text { analysis }\end{array}$ \\
\hline
\end{tabular}

Source: The author 2020

accessibility. On the other hand, this paper has sought to expand the depth and orientation of the existing research on the adaptive reuse of architectural heritage. The research frameworks, mixed research methodologies, and assessment methods (MCDM and PMM) could be extended to different architectural heritage scales and adaptive reuse studies with different perspectives in the future.

\section{Abbreviations}

AHP: Analytic hierarchy process; ANP: Analytic network process; BIM: Building information modelling; BU: Bottom-up; DEMATEL: Decision making trail and evaluation laboratory; EU: European Union; Five-MMR: Mixed-Method Research Framework with Five Domains; FWINGS: Fuzzy extensions on weighted influence non-linear gauge system; HUL: Historic urban landscape; MAVT: Multi-attribute value theory; MCDM: Multi-criteria decision model; MEC: Means-end chain; PC: People-centred; PMM: Preference measurement model; PROMETHEE: Preference Ranking Organization Method for Enrichment of Evaluations; SD: Semantic differential; SP: Stated preference; TD: Top-down; UNESCO: United Nations Educational, Scientific and Cultural Organization; VEP: Visitor-employed photography; WASPAS: Weighted aggregated sum product assessment; WTP: Willingness to pay

\section{Acknowledgements}

Not applicable.

\section{Authors' contributions}

Yuan Li: Conceptualization, Methodology; Long Zhao: Data curation, WritingOriginal draft preparation; Jingxiong Huang: Data curation, Writing-Original draft preparation; Andrew Law: Writing- Reviewing and Editing. All authors read and approved the final manuscript.

\section{Funding}

This work was supported by the Natural Science Foundation of China (grant numbers 41671141), the Natural Science Fund of Fujian Province of China (2020J01011), Xiamen Science and Technology Bureau (grant numbers 3502Z20183005), Xiamen Construction Bureau (grant numbers XJK2019-1-9).

\section{Availability of data and materials}

Not applicable.

\section{Declarations}

\section{Competing interests}

The authors declare that they have no competing interests.

\section{Author details}

${ }^{1}$ School of Architecture and Civil Engineering, Xiamen University, No. 422, Siming South Road, Xiamen 361005, Fujian, China. ${ }^{2}$ Xiamen Key Laboratory of Digital Protection and Application for Cultural Heritage, Xiamen 361005, China. ${ }^{3}$ School of Architecture, Planning and Landscape, Newcastle University, Newcastle upon Tyne NE1 7RU, UK.
Received: 25 September 2020 Accepted: 25 March 2021

Published online: 04 May 2021

\section{References}

Abascal, Trinidad Espinosa. 2019. "Indigenous Tourism in Australia: Understanding the Link between Cultural Heritage and Intention to Participate Using the Means-end Chain Theory." Journal of Heritage Tourism 14 (3): 263-281. https://doi.org/10.1080/1743873X.2018.1549053.

Abdullah, S., A. Markandya, and P. Nunes. 2011. "Introduction to Economic Valuation Methods." In Research Tools in Natural Resource and Environmental Economics, edited by Amitrajeet A Batabyal and Peter Nijkamp, 143-187. Hackensack, NJ: World Scientific Publishing Co. Pte. Ltd.

Amaratunga, D., D. Baldry, M. Sarshar, and R. Newton. 2002. "Quantitative and Qualitative Research in the Built Environment: Application of the 'Mixed' Research Approach." Work Study 51 (1): 17-31. https://doi.org/10.1108/0043 8020210415488

Bapiri, J., K. Esfandiar, and S. Seyfi. 2020. "A Photo-elicitation Study of the Meanings of a Cultural Heritage Site Experience: A Means-end Chain Approach." Journal of Heritage Tourism 16 (1): 1-17. https://doi.org/10.1080/1 743873X.2020.1756833.

Berta, Mauro, Marta Bottero and Valentina Ferretti. 2016. "A Mixed-methods Approach for the Integration of Urban Design and Economic Evaluation: Industrial Heritage and Urban Regeneration in China." Environment and Planning B: Planning and Design 45 (2): 1-53. https://doi.org/10.1177/0265813 516669139

Boom. 2018. Imprint of action: The sociocultural impact of public activities in archaeology, 26-29. Doctoral dissertation, Leiden: Leiden University.

Bottero, M., C. D'Alpaos, and A. Oppio. 2019. "Ranking of Adaptive Reuse Strategies for Abandoned Industrial Heritage in Vulnerable Contexts: A Multiple Criteria Decision Aiding Approach." Sustainability 11 (3): 785. https:// doi.org/10.3390/su11030785.

Bullen, P., and P. Love. 2009. "Residential Regeneration and Adaptive Reuse: Learning from the Experiences of Los Angeles." Structural Survey 27 (5): 351360. https://doi.org/10.1108/02630800911002611.

Bullen, P. and P. Love. 2011. "Adaptive Reuse of Heritage Buildings." Structural Survey 29 (5): 411-421. https://doi.org/10.1108/02630801111182439.

Cameron, R. 2011. "Mixed Methods Research: The Five Ps Framework." Electronic Journal of Business Research Methods 9 (2): 96-108.

Campbell, S. 2016. "The Planner's Triangle Revisited: Sustainability and the Evolution of a Planning Ideal That Can't Ctand Still." Journal of the American Planning Association 82 (4): 388-397. https://doi.org/10.1080/01944363.201 6.1214080.

Chapman, A. 2004. "Technology as World Building." Ethics, Place and Environment 7 (1-2): 59-72. https://doi.org/10.1080/1366879042000264778.

Chen, Chia-Sheng, Yin-Hao Chiu, and Li-chiu Tsai. 2018. "Evaluating the Adaptive Reuse of Historic Buildings through Multicriteria Decision-making." Habitat International 81: 12-23. https://doi.org/10.1016/j.habitatint.2018.09.003.

Chilisa, B. and G. Tsheko. 2014. "Mixed Methods in Indigenous Research: Building Relationships for Sustainable Intervention Outcomes." Journal of Mixed Methods Research 8 (3): 222-233. https://doi.org/10.1177/1558689814527878.

Coeterier, J. F. 2002. "Lay People's Evaluation of Historic Sites." Landscape and Urban Planning 59 (2): 111-123. https://doi.org/10.1016/S0169-2046(02)000075.

Creswell. 2010. "Mapping the Developing Landscape of Mixed Methods Research. " In Sage Handbook of Mixed Methods in Social and Behavioral Research, edited by A. Tashakkori and C. Teddlie, 45-68. Thousand Oaks: Sage. 
Department of the Environment and Heritage, Australian Government. 2004. "Adaptive Reuse: Preserving Our Past, Building Our Future." https://www. environment.gov.au/heritage/publications/adaptive-reuse.

Dümcke, C., and M. Gnedovsky. 2013. The Social and Economic Value of Cultural Heritage: Literature Review. European Expert Network on Culture.

Elsorady, D. 2020. "Adaptive Reuse Decision Making of a Heritage Building Antoniadis Palace, Egypt." International Journal of Architectural Heritage 14 (5): 658-677. https://doi.org/10.1080/15583058.2018.1558313.

Esfandiar, K., and J. Bapiri. 2016. "Exploring Visitor Meanings at a Heritage Setting: A Means-end Approach." In ECU Business Doctoral and Emerging Scholars' Colloquium, 130-136. Perth: ECU SBL Australia.

Europa Nostra. 2015. "Cultural Heritage Counts for Europe Consortium." https:// www.europanostra.org/our-work/policy/cultural-heritage-counts-europe/.

European Leader Association for Rural Development. 2016. "The Leader Approach." https://enrd.ec.europa.eu/leader-clld/leader-toolkit/leaderclldexplained_en.

Fayad, S., and L. Kendal. 2020. "Local Innovation and Leadership from Regional Victoria: The City of Ballarat and UNESCO's Historic Urban Landscape Approach." In Located research, edited by A. Campbell, M. Duffy and B. Edmondson, 71-88. Singapore: Palgrave Macmillan. https://doi.org/10.1007/ 978-981-32-9694-7_6.

Fedorczak-Cisak, M., A. Kowalska-Koczwara, F. Pachla, E. Radziszewska-Zielina, B. Szewczyk, G. Śladowski, and T. Tatara. 2020. "Fuzzy Model for Selecting a Form of Use Alternative for a Historic Building to be Subjected to Adaptive Reuse." Energies 13 (11): 24.

Feilden, B. 2007. Conservation of Historic Buildings. Abingdon: Routledge. https:// doi.org/10.4324/9780080502915.

Ferretti, V., M. Bottero, and G. Mondini. 2014. "Decision Making and Cultural Heritage: An Application of the Multi-attribute Value Theory for the Reuse of Historic Buildings." Journal of Cultural Heritage 15 (6): 644-655. https://doi. org/10.1016/j.culher.2013.12.007.

Forman, E. and S. Gass. 2001. "The Analytical Hierarchy Process: An Exposition. " Operations Research 49 (4): 469-487. https://doi.org/10.1287/opre.49.4.4 69.11231.

Glogowska, M. 2011. "Paradigms, Pragmatism, and Possibilities: Mixed-methods Research in Speech and Language Therapy." International Journal of Language \& Communication Disorders 46 (3): 251-260. https://doi.org/10.31 09/13682822.2010.507614

Glumac, B., and N. Islam. 2020. "Housing Preferences for Adaptive Re-use of Office and Industrial Buildings: Demand-side." Sustainable Cities and Society 62: $1-8$.

González-Tennant, E.. 2013. "New Heritage and Dark Tourism: A Mixed Methods Approach to Social Justice in Rosewood, Florida." Heritage \& Society 6 (1): $62-$ 88. https://doi.org/10.1179/2159032X13Z.0000000007.

Günce, K., and D. Misirlisoy. 2014. "Adaptive Reuse of Military Establishments as Museums: Conservation vs. Museography." WIT Transactions on The Built Environment 143: 125-136.

Hettema, J. and L. Egberts. 2019. "Designing with Maritime Heritage: Adaptive Reuse of Small-scale Shipyards in Northwest Europe." Journal of Cultural Heritage Management and Sustainable Development 10 (2): 130-143. https:// doi.org/10.1108/JCHMSD-04-2019-0032.

Ho, Chaangiuan, Tsaiyuan Liao, Shuchin Huang, and Huimei Chen. 2015. "Beyond Environmental Concerns: Using Means-end Chains to Explore the Personal Psychological Values and Motivations of Leisure/Recreational Cyclists." Journal of Sustainable Tourism 23 (2): 234-254. https://doi.org/10.1080/09669582.2 014.943762.

ICCROM. 2015. People-centred Approaches to the Conservation of Cultural Heritage: Living Heritage. Rome: International Centre for the Study of the Preservation and Restoration of Cultural Property.

İpekoğlu, B. 2006. "An Architectural Evaluation Method for the Conservation of Traditional Dwellings." Building and Environment 41 (3): 386-394. https://doi. org/10.1016/j.buildenv.2005.02.009.

Jiang, Shan, N. Scott, and Peiyi Ding. 2015. "Using Means-end Chain Theory to Explore Travel Motivation: An Examination of Chinese Outbound Tourists. " Journal of Vacation Marketing 21 (1): 87-100. https://doi.org/10.1177/13 56766714535599.

Kang, Jian, and Mei Zhang. 2002. "Semantic Differential Analysis on the Soundscape of Urban Open Public Spaces." The Journal of the Acoustical Society of America 112 (5): 2435. https://doi.org/10.1121/1.4779999.

Katahenggam, N.. 2020. "Tourist Perceptions and Preferences of Authenticity in Heritage Tourism: Visual Comparative Study of George Town and Singapore.
" Journal of Tourism and Cultural Change 18 (4): 371-385. https://doi.org/10.1 080/14766825.2019.1659282.

Khadka, C. and H. Vacik. 2012. "Comparing a Top-down and Bottom-up Approach in the Identification of Criteria and Indicators for Sustainable Community Forest Management in Nepal." Forestry: An International Journal of Forest Research 85 (1): 145-158. https://doi.org/10.1093/forestry/cpr068.

Khoo-Lattimore, C., P. Mura, and R. Yung. 2019. "The Time has Come: A Systematic Literature Review of Mixed Methods Research in Tourism." Current Issues in Tourism 22 (13): 1531-1550. https://doi.org/10.1080/13683500.201 7.1406900 .

Klenosky, D. 2002. "The 'Pull' of Tourism Destinations: A Means-end Investigation. " Journal of Travel Research 40 (4): 385-395. https://doi.org/10.1177/00472 87502040004005

Kroes, E. P., and R. J. Sheldon. 1988. "Stated Preference Methods: An Introduction. " Journal of Transport Economics and Policy: 11-25.

Law, A. and Qianqian Qin. 2017. "Searching for Economic and Cosmopolitan Roots: Historical Imaginaries and 'Hankou Merchant Port Nostalgia' in the central Chinese city of Wuhan." Journal of the Faculty of Architecture, JFA. http://jfa.arch.metu.edu.tr/archive/0258-5316/articles/metujfa2017214.pdf.

Lin, Chinfeng, and Chensu Fu. 2020. "Cognitive Implications of Experiencing Religious Tourism: An Integrated Approach of Means-end Chain and Social Network Theories." International Journal of Tourism Research 22 (1): 71-80. https://doi.org/10.1002/jtr.2319.

Ma, Kuenwai, Haiming Wong, and Cheukming Mak. 2018. "A Systematic Review of Human Perceptual Dimensions of Sound: Meta-analysis of Semantic Differential Method Applications to Indoor and Outdoor Sounds." Building and Environment 133: 123-150. https://doi.org/10.1016/j.buildenv.2018.02.021.

Mazzanti, M. 2002. "Cultural Heritage as Multi-dimensional, Multi-value, and Multiattribute Economic Good: Toward a New Framework for Economic Analysis and Valuation." The Journal of Socio-Economics 31 (5): 529-558. https://doi. org/10.1016/S1053-5357(02)00133-6.

McGehee, N. and K. Andereck. 2004. "Factors Predicting Rural Residents' Support for Tourism." Journal of Travel Research 43 (2): 131-140. https://doi.org/10.11 77/0047287504268234.

McIntosh, A. J., and M. A. Thyne. 2005. "Understanding Tourist Behavior Using Means-end Chain Theory." Annals of Tourism Research 32 (1): 259-262. https://doi.org/10.1016/j.annals.2004.05.005.

Misirlisoy, D., and K., Gunce. 2016. "Adaptive Reuse Strategies for Heritage Buildings: A Holistic Approach." Sustainable Cities and Society 26: 91-98. https://doi.org/10.1016/j.scs.2016.05.017.

Molina-Azorín, J., and X. Font. 2016. "Mixed Methods in Sustainable Tourism Research: An Analysis of Prevalence, Designs, and Application in JOST (20052014)." Journal of Sustainable Tourism 24 (4): 549-573. https://doi.org/10.1 080/09669582.2015.1073739.

Morgan, D. L. 2007. "Paradigms Lost and Pragmatism Regained." Journal of Mixed Methods Research 1 (1): 48-76. https://doi.org/10.1177/2345678906292462.

Mualam, N., and R. Alterman. 2020. "Architecture Is Not Everything: A Multifaceted Conceptual Framework for Evaluating Heritage Protection Policies and Disputes." International Journal of Cultural Policy 26 (3): 291-311. https:// doi.org/10.1080/10286632.2018.1518978.

Nadeau, R., and M. Landry. 1986. L'aide à la Décision: Nature, Instruments et Perspectives D'avenir. Québec: Presses Université Laval.

Najd, M. D., N. A. Ismail, S. Maulan, M. Y. M. Yunos, and M. D. Niya. 2015. Visual preference dimensions of historic urban areas: The determinants for urban heritage conservation. Habitat International 49: 115-125. https://doi.org/10.1 016/j.habitatint.2015.05.003.

Oppermann, M. 2000. "Triangulation: A Methodological Discussion." International Journal of Tourism Research 2 (2): 141-145. https://doi.org/10.1002/(SICI)1 522-1970(200003/04)2:2<141:.:AID-JTR217>3.0.CO;2-U.

Oppio, A., M. Bottero, and V. Ferretti. 2017. "Designing Adaptive Reuse Strategies for Cultural Heritage with Choice Experiments." In Appraisal: From theory to practice, edited by S. Stanghellini, P. Morano, M. Bottero, and A. Oppio, 303315. Cham: Springer.

Osgood, C. E., G. J. Suci, and P. Tannenbaum. 1957. The Measurement of Meaning. Champaign: University of Illinois Press.

Panwar, M. S., and S. Thapliyal. 2017. "The Concept of Urban Sustainability: The Key Component in Achieving Sustainable Development of Cities." International Journal of Scientific Research in Science, Engineering and Technology 3 (8): 958-963.

Pavlovskis, M., D. Migilinskas, J. Antucheviciene, and V. Kutut. 2019. "Ranking of Heritage Building Conversion Alternatives by Applying BIM and MCDM: A Case of Sapieha Palace in Vilnius." Symmetry-Basel 11 (8): 26. 
Pendlebury, J. 2008. Conservation in the Age of Consensus. Abingdon: Routledge. https://doi.org/10.4324/9780203892343

Ribera, F., A. Nesticò, P. Cucco, and G. Maselli. 2020. "A Multicriteria Approach to Identify the Highest and Best Use for Historical Buildings." Journal of Cultural Heritage 41: 166-177. https://doi.org/10.1016/j.culher.2019.06.004.

Rokeach, M. 1973. The Nature of Human Values. New York: Free press.

Saaty, R. W. 1988. "What is the Analytic Hierarchy Process?" In Mathematical models for decision support, 109-121. Cham: Springer.

Saaty, T. L., and L. G. Vargas. 2006. Decision Making with the Analytic Network Process. Cham: Springer.

Sham, D. H-M. 2015. "Heritage as Resistance: Preservation and Decolonization in Southeast Asian Cities, 14-15. Doctoral dissertation, London: Goldsmiths, University of London.

Shao, Dan, Y. Nagai, and R. Sosa. 2019. "Design for Sustainability and Innovation: A Kansei Engineering Evaluation of the Adaptive Reuse of Old Buildings." Proceedings of the Design Society: International Conference on Engineering Design 1 (1): 3221-3230

Shehata, W. T. A., Y. Moustafa, L. Sherif, and A. Botros. 2015. "Towards the Comprehensive and Systematic Assessment of the Adaptive Reuse of Islamic Architectural Heritage in Cairo." Journal of Cultural Heritage Management and Sustainable Development 5 (1): 14-29. https://doi.org/10.1108/JCHMSD-02-2 014-0003.

Silva, J. A., and A. W. Mosimane. 2012. "Conservation-based Rural Development in Namibia." The Journal of Environment and Development 22 (1): 25-50.

Sokołowicz, M. E. and Z. Przygodzki. 2020. "The Value of Ambiguous Architecture in Cities. The Concept of a Valuation Method of $20^{\text {th }}$ Century Post-socialist Train Stations." Cities 104: 102786.

Srinivas, H. 2015. "Heritage and Conservation Strategies: Understanding the Justifications and Implications." Policy Analysis series E-100. https://www.gdrc. org/heritage/heritage-strategies.html.

Stober, D., I. Brkanić, and L. Lončar. 2018. "The Preferences of Residents and Tourists for Cultural and Architectural Heritage in a Rural Landscape: The Case of Zlatna Greda, Croatia." Moravian Geographical Reports 26 (4): 285-297. https://doi.org/10.2478/mgr-2018-0023.

Suedel, B. C., J. Kim, and C. J. Banks. 2009. "Comparison of the Direct Scoring Method and Multi-criteria Decision Analysis for Dredged Material Management Decision Making." Engineer Research and Development Center Vicksburg Ms Environmental Lab. https://citeseerx.ist.psu.edu/viewdoc/ download?doi=10.1.1.847.746\&rep=rep1\&type=pdf.

Townsend, L. 2015. Effective Strategic Planning, Planet Training Notes. Planning Institute of Australia. Retrieved from Campbell, Duffy, and Michelle, Edmondson (Eds.). 2020. Located Research: Regional places, transitions and challenges. London: Palgrave Macmillan.

Tu, Hungming. 2020. "The Attractiveness of Adaptive Heritage Reuse: A Theoretical Framework." Sustainability 12 (6): 2372. https://doi.org/10.3390/ su12062372.

UNESCO. 2011. Recommendation on the Historic Urban Landscape. http://portal. unesco.org/en/ev.php-URL_ID=48857\&URL_DO=DO_TOPIC\&URL_SECTION= 201. Html.

Vallance, S., H. C. Perkins, and J. E. Dixon. 2011. "What is Social Sustainability? A Clarification of Concepts." Geoforum 42 (3): 342-348. https://doi.org/10.1016/j. geoforum.2011.01.002.

Vardopoulos, I. 2019. "Critical Sustainable Development Factors in the Adaptive Reuse of Urban Industrial Buildings. A Fuzzy DEMATEL Approach." Sustainable Cities and Society 50: 1-12.

Veldpaus, L. 2015. "Historic Urban Landscapes: Framing the Integration of Urban and Heritage Planning in Multilevel Governance." Doctoral dissertation, Eindhoven: Eindhoven University of Technology.

Wang, Weishan. 2017. "Conservation of Community Life and Active Utilization of Buildings in the World Cultural Heritage Site of Kulangsu." Shanghai Urban Planning Review 137 (6): 23-27.

Wang, Huey-Jiun and Zeng, Zhi-Teng. 2010. "A Multi-objective Decision-making Process for Reuse Selection of Historic Buildings." Expert Systems with Applications 37 (2): 1241-49. https://doi.org/10.1016/j.eswa.2009.06.034.

Wassenberg, C. L., M. A. Goldenberg, and K. E. Soule. 2015. "Benefits of Botanical Garden Visitation: A Means-end Study." Urban Forestry \& Urban Greening 14 (1): 148-155. https://doi.org/10.1016/j.ufug.2015.01.002.

Whitehand, J. W. R. 2014. "Towards an Integrated Approach to Cultural Heritage for Europe." In Communication from the commission to the European Parliament, the Council, the European Economic and Social Committee and the Committee of the Regions, COM (2014), 477.
Willson, J., and A. Mclntosh. 2010. "Using Photo-based Interviews to Reveal the Significance of Heritage Buildings to Cultural Tourism Experiences." Cultural Tourism Research Methods 7: 141-155.

Wisdom, J., and J. W. Creswell. 2013. Mixed Methods: Integrating Quantitative and Qualitative Data Collection and Analysis while Studying Patient-centered Medical Home Models. Rockville: Agency for Healthcare Research and Quality.

Yıldırım, M., and G. Turan. 2012. "Sustainable Development in Historic Areas: Adaptive Reuse Challenges in Traditional Houses in Sanliurfa, Turkey." Habitat International 36 (4): 493-503. https://doi.org/10.1016/j.habitatint.2012.05.005.

Yung, E. H. K., and E. W. H. Chan. 2011. "Problem Issues of Public Participation in Built-heritage Conservation: Two Controversial Cases in Hong Kong." Habitat International 35 (3): 457-466. https://doi.org/10.1016/j.habitatint.2010.12.004.

\section{Publisher's Note}

Springer Nature remains neutral with regard to jurisdictional claims in published maps and institutional affiliations.

\section{Submit your manuscript to a SpringerOpen ${ }^{\circ}$ journal and benefit from:}

- Convenient online submission

- Rigorous peer review

- Open access: articles freely available online

High visibility within the field

- Retaining the copyright to your article

Submit your next manuscript at $\boldsymbol{\nabla}$ springeropen.com 